\title{
The Spanish blackspot seabream (Pagellus bogaraveo) fishery in the Strait of Gibraltar: spatial distribution and fishing effort derived from a small-scale GPRS/GSM based fisheries vessel monitoring system
}

\author{
Candelaria BURGos ${ }^{1, a}$, Juan GIL ${ }^{1}$ and Luis Alberto DEL OLMO ${ }^{2}$ \\ ${ }^{1}$ Instituto Español de Oceanografía, C.O. de Cádiz, Muelle de Levante s/n, Puerto Pesquero, 11006 Cádiz, Spain \\ 2 Consejería de Agricultura y Pesca, Junta de Andalucía, C/ Tabladilla s/n, 41013 Sevilla, Spain
}

Received 1st August 2013; Accepted 13 November 2013

\begin{abstract}
This paper aims to investigate the potential interest of using a Vessel Monitoring System (VMS) based on GPRS/GSM (Global System for Mobile Communications) technology to obtain a better estimation of fishing activity and distribution of a small-scale artisanal fleet, for which the European satellite-based system is not available. Since the early 1980s, the artisanal fishery targeting blackspot seabream (Pagellus bogaraveo), commonly known as "voraz", has been developing along the Strait of Gibraltar area. Up to now the fishing effort was estimated using the number of sales, a proxy for the number of fishing days. This measure does not, however, capture the "missing effort", i.e., fishing days resulting in no catch or not enough catch to be sold at public auction. The European satellite-based VMS provides information about the dynamics of different fishing fleets, but is not installed on small vessels $(<15 \mathrm{~m})$, such as those used by the artisanal "voracera" fleet targeting blackspot seabream in the Strait of Gibraltar. The Andalucía Regional Government installed its own vessel monitoring system on several artisanal fleets using GPRS/GSM cellular network technology that sends data on vessel positions and speed every three minutes. Data collected from 2009 to 2011 using this system were filtered and analysed to estimate fishing effort, catch rates and the spatial distribution of the blackspot seabream fishery. The estimates obtained seem to provide a good representation of fishery reality. As expected, the missing effort increases as the resource levels decrease. Additionally, expert knowledge of the fishery allowed application of an algorithm for splitting these daily trips into estimated fishing hauls. Afterwards the spatial distribution of catches and Catch per Unit Effort (CPUE) could be obtained linking VMS locations with landings information. This study provides a considerably finer spatial scale view of the fishery than data available in the past.
\end{abstract}

Keywords: Fishing effort / Spatial distribution / VMS / Artisanal fishery / Pagellus bogaraveo / Strait of Gibraltar

\section{Introduction}

Since the early 1980s, an artisanal fishery targeting the blackspot seabream (Pagellus bogaraveo), named besugo in Spanish, has developed in the Strait of Gibraltar. Blackspot seabream caught in the Strait of Gibraltar is marketed as "Voraz" or "Voraz de Tarifa", an officially registered label used as guarantee of quality. The vessels that participate in this fishery are mainly from two Spanish ports, Tarifa and Algeciras, and use the "voracera", a locally designed and built mechanized hook line baited with sardine (Padillo et al. 2001; Gil 2006). Fishing is carried out taking advantage of ebb and flow in the Strait over bottoms from 350 to $700 \mathrm{~m}$ depth. The fishery began in the early 1980s. In 1983, the fleet comprised about 25 boats. It increased to more than 100 boats in the

\footnotetext{
a Corresponding author: caleli.burgos@cd.ieo.es
}

early 1990s and slightly decreased thereafter to 94 authorized fishing boats in 2011, as a consequence of the regulations established in late 2009 by the Regional Government's (Junta de Andalucía) recovery plan for the blackspot seabream in the Strait of Gibraltar. The Spanish blackspot seabream fishery in the Strait of Gibraltar is almost a single species fishery in which the target species represents $74 \%$ of the total landings in weight, and $91 \%$ in value (more than EUR 5 million in 2010). Landings from this fishery represent almost $70 \%$ of the total blackspot seabream landings in ICES Subarea IX (ICES, 2012a). Hence, the voracera fleet is the main fishing fleet for this species of the west of Iberia and this fleet is strongly dependent upon its target species, with a well-defined fleet component (group of vessels developing the same fishing pattern through the year) (Silva et al. 2002).

The landings increased to about 854 tonnes in 1994, but decreased rapidly to $282 \mathrm{t}$ in 1998 . The decrease in landings 
in 1997 raised serious concerns. The Instituto Español de Oceanografía (IEO) started monitoring the fishery, following a request from the Fishermen's brotherhoods, cooperative producer organizations representing the economic and social interests of the fishing sector, which contributes to the local development, social cohesion and sustainability.

In 1998, the Spanish Government introduced several technical measures in fishery management. The next year, in 1999, the Andalusian Regional Government developed a fishing plan for the blackspot seabream fishery, including a closed season of two months in February and March, a minimum hook size regulation, a maximum number of hooks per line (set to 100), a maximum number of lines (30) and automatic hauling machines (3) per boat, and a minimum fish length at landing $(33 \mathrm{~cm})$ (BOE No. 157 of July 2, 1998). Fisheries for blackspot seabream required better management, as this species can only sustain low fishing mortality and the biomass of fecund females may be strongly depleted by fishing young ages (Lorance 2011). Additionally, a European Union Total Allowable Catch (TAC) was introduced in 2003 as part of council regulation (EC) No. 2340/2002 of 16 December 2002 fixing the fishing opportunities for deep-sea fish stocks for 2003 and 2004.

Fishing effort can be measured in several units. For a hook fishery, it can be quantified in terms of the number of fishing days, fishing sets or the number of hooks deployed. In the case of the blackspot seabream fishery, the only effort data available was the number of sales of the target species at the auction markets in the ports of Tarifa and Algeciras. However, for this effort unit to actually provide a reliable measure of the fishing activity, there must be a sale after every fishing day and experience proves that some fishing days do not result in a catch any others in a catch worth selling. In other words, some fishing days are not accounted for when using the number of sales to measure fishing effort. These unaccounted fishing days are known as "missing effort" (Gil et al. 2005; ICES 2011). Thus, if the proportion of missing effort varies over years, this measure does not allow a proper calculation of catch per unit of effort (CPUE), which is a suitable stock abundance indicator. This is particularly the case in data-limited situations such as the present one, where there is no survey indicator, no yearly age composition, and no agreed-upon scheme for age estimation (Lorance et al. 2010; ICES 2012b).

Under the European common fisheries policy, satellitebased Vessel Monitoring Systems (VMS) were adopted and electronic devices (called blue boxes) were installed on board vessels longer than $15 \mathrm{~m}$ to monitoring fishing activities (EC commission regulation No. 2244/2003 of 18 December 2003, laying down detailed provisions regarding satellite-based Vessel Monitoring Systems). VMS provide information about the spatio-temporal distribution of different fishing fleets. Because the voracera fleet is fully artisanal, the boats involved are smaller than $15 \mathrm{~m}$ and thus not subject to VMS. Nevertheless, since 2004, the Andalusian Regional Government started installing its own monitoring system, called SLSEPA ("Sistema de Localización y Seguimiento de Embarcaciones Pesqueras Andaluzas") on smaller vessels. Most vessels are now equipped with these systems. SLSEPA devices aim to ensure the safety at sea, control fishing activity, and improve the monitoring and assessment of fisheries resources. In this study, we performed an analysis of this high spatial and temporal resolution data to identify the preferred fishing areas, steaming routes and sequence of fishing operations of the voracera fleet.

Most stock assessments assume that fishing effort is randomly distributed within known fishing grounds (Hilborn and Walters 1992). However, the advent and wide use of VMS in many fisheries increases the potential for using these data to improve spatially explicit fishery models (Die and Ellis 1999). As a first step, real figures of fishing days are provided as well as the estimated number of hauls (fishing operations) per boat. Additionally, landings (and CPUE) geographical distributions could be drawn, linking VMS data with their respective sales at landing port.

\section{Materials and methods}

\subsection{Information source}

SLSEPA data from the Strait of Gibraltar voracera fleet were available for the period 2009 to 2011. Boats carry a device, regionally called "green boxes" (to differentiate them from the EU VMS "blue boxes"), that transmit hour and positions (provided by GPS), course and speed to the control centre every three minutes. Data transmission uses technology of the cellular networks General Packet Radio Service/Global System for Mobile Communications (GPRS/GSM) instead of a satellite system to send data, based on reports that have evaluated possible alternatives and on the study of the coverage of these networks on the Andalusian coast (Del Olmo 2006). In case of loss of coverage, data are kept in an internal queue and are dumped to the data control centre once the coverage is recovered.

First, the data received from SLSEPA devices were preprocessed by the control centre of the Department of Agriculture and Fisheries of the Andalucía Regional Government. Transmission errors, records on land, and records at speeds higher than 5 knots were excluded, being associated with vessel steaming activities. Methods to discriminate fishing and non-fishing activities from VMS data have been studied in several fisheries (see review in Lee et al. 2010). This preprocessing allows the transmission of smaller data to IEO without losing data of interest for this study, as previous observations of fishing activity of voracera fleet (observers on board program) demonstrated that the speed associated with fishing activity is less than 4 knots. Later, at the IEO Oceanographic Centre of Cadiz, SLSEPA data were integrated into an MS Access database for management and subsequent incorporation into a Geographic Information System (GIS) using the ArcGIS (ESRI) software for processing and mapping.

\subsection{Filtering process}

Only records having the signal "in port" turned off (a switch must be on when vessels are in port) and speed values less than 4 knots were selected, based on the assumption that this is the maximum speed during fishing operations. The limit of 4 knots was selected based on knowledge from on-board 
fisheries observers. Additionally, records at entries and exits from main ports and over shallow locations (<30 m depth) were removed based on the GIS processing of the data. Port areas were delimited by a buffer of 1 nautical miles around Tarifa, Barbate and Ceuta ports (were a few vessels are based or operate occasionally) and inside Algeciras Bay. For depth criteria, GEBCO bathymetry was used. Although the resolution and accuracy of GEBCO is low, it was considered sufficient for the purpose of this paper.

\subsection{Association with target species}

The voracera fleet not only targets blackspot seabream, but also fishes Atlantic bluefin tuna (Thunnus thynnus) and silver scabbardfish (Lepidopus caudatus) using a different fishing gear. Fishing trips resulting in sales were associated with one of these three target species using the landings statistics database, which includes quantities sold by species per vessel and per day. Fishing trips resulting in landings of Atlantic bluefin tuna or silver scabbardfish were excluded and used as a base to delimit their respective fishing areas using spatial statistics tools. Records without associated landings, but located in the fishing areas of these two species, were ascribed to these fisheries and excluded.

The remaining records correspond to fishing operations targeting blackspot seabream, including those that resulted in no catch. In other words, this filtering process provides exhaustive and high spatio-temporal resolution effort data for the Spanish blackspot seabream fishery in the Strait of Gibraltar.

\subsection{Fishing effort and CPUE}

The only previous estimate of the fishing effort targeting the blackspot seabream before the present study was the number of sales of this species (one vessel fishing for the species for one day makes one sale).

Dividing the total landings by the number of sales, a crude $C P U E$, further referred to as CPUE1, can be calculated. As sales and landings data are available by vessel, $C P U E 1$ can be calculated for the total voracera fleet or for any smaller fleet. For the total fleet, $C P U E 1$ is expressed as:

$$
C P U E 1_{\text {Total }}=L_{\text {Total }} / S_{\text {Total }},
$$

where $L_{\text {Ttotal }}$ are total blackspot seabream landings (in $\mathrm{kg}$ ) and $S_{\text {Total }}$ is the total number of sales. CPUE1 was calculated for both the total fleet and the sub-fleet of vessels equipped with a SLSEPA device.

$C P U E 1$ does not account for fishing effort that does not result in a sale of this species.

The number of fishing days targeting blackspot seabream for boats equipped with the SLSEPA device can be directly derived from the filtering process and association to the target species described above. A second $C P U E$ estimator, further referred to as $C P U E 2$, can then be obtained by dividing the blackspot seabream landings from boats equipped with a SLSEPA device by this number of fishing days:

$$
C P U E 2=L_{\mathrm{SLSEPA}} / D_{\mathrm{SLSEPA}},
$$

where $L_{\text {SLSEPA }}$ are the blackspot seabream landings of boats equipped with SLSEPA devices and $D_{\text {SLSEPA }}$ is the number of fishing day targeting this species by these boats, estimated from the SLSEPA device data analysis.

Although the proportion of vessels having installed SLSEPA devices increased to reach more than $95 \%$ in 2011 (88\% in 2009 and $89 \%$ in 2010), not all vessels targeting blackspot seabream are equipped yet. Therefore, the estimation of the total number of fishing days for blackspot seabream by the total voracera fleet was calculated by raising the number of fishing days of vessels equipped with the SLSEPA device to the total fleet according to landings:

$$
D_{\text {Total }}=L_{\text {Total }} / L_{\text {SLSEPA }} \times D_{\text {SLSEPA }}=L_{\text {Total }} / C P U E 2 .
$$

The missing effort (number of fishing days not resulting in a sale) can then be calculated by subtracting $S_{\text {Total }}$ from $D_{\text {Total }}$ and the proportion of missing effort was calculated as:

$$
P_{\text {Missing }}=\left(D_{\text {Total }}-S_{\text {Total }}\right) / D_{\text {Total }} \text {. }
$$

It is worth noting that only one fishing trip per day per vessel is allowed as a part of the fishing effort control measures included in the recovery plan for this fishery.

\subsection{Estimation of the number of fishing operations (hauls)}

Fishing operations (hauls) for a given day were separated using an algorithm that incorporates expert knowledge of the fishery and data from observers on board. Based on this knowledge, a voracera fishing haul lasts from 15 to 60 minutes. The speed of the boat may briefly increase over 4 knots during a haul in order to reset the position of the vessel (because of the tides force).

Taking those facts into account, consecutive records were assumed to form a single haul when no speed increase beyond 4 knots lasting more than 6 min was detected, i.e., the time interval between two records is equal or less than 6 min, since the filtering process deleted records with a speed greater than 4 knots. When the time interval between records is greater than $6 \mathrm{~min}$, the haul is considered finished and the next series of records in the filtered data corresponds to a new haul.

The estimated number of hauls was cross-validated using the reported information from the observers on board the voracera fleet in 2009. A total of 68 observed trips on board three different vessels throughout the whole year were used for validation; the number of hauls per day reported by observers was compared to corresponding estimates derived from SLSEPA data.

\subsection{Spatial distribution}

The spatial distribution of the hauls was estimated by summing the number of hauls within 1 square nautical mile $\left(\mathrm{nmi}^{2}\right)$ grid cells, a sufficient resolution based on the total size of study area (around $650 \mathrm{nmi}^{2}$ ), the covered distance in a maximum duration haul at average speed $\left(60^{\prime} \times 1 \mathrm{knot}\right)$ and the mean distance between usually frequented fishing grounds $(0.8 \mathrm{nmi})$. 
This mean distance was obtained by spatial analysis tools from fishing grounds previously described (Gil et al. 2006). The total landings per boat and per day were apportioned among the hauls of the same day according to haul durations. Then, the CPUE per grid cell per year was calculated as landings per cell divided by the number of hauls per cell:

$$
C P U E 3(\mathrm{c})=L_{\mathrm{SLSEPA}}(\mathrm{c}) / D_{\mathrm{SLSEPA}}(\mathrm{c})
$$

where c stands for a cell of the spatial grid.

\section{Results}

SLSEPA data from 2009 to 2011 provided by the Andalucía Regional Government only include records where vessel speed was lower than 5 knots. The distribution of these data shows that the activity of the voracera fleet is confined to a relatively small area, mainly in the Strait of Gibraltar with an extension to the southwest of Barbate. Activities increased from 2009 to 2011, with the westernmost fishing ground hardly visited before 2011 (Fig. 1). In the Mediterranean Sea (north-east on the map), there was more coastal activity in 2010. By removing records near ports and in shallow waters, the filtering process excluded records with vessel speeds ranging from 0 to 0.3 knots. The resulting fishing activity was characterized by a mode at 1 knot for the three years analysed (Fig. 2). This distribution represents well what is known of the voracera fishing method in this region, where a low speed is maintained during a haul to steer the line against the strong currents of the Strait of Gibraltar. No change of the distribution and mode of the raw and filtered speed was observed between years (2009-2011).

Association with target species showed that fishing for tuna occurs in the central area of the Strait of Gibraltar, well delimited by the $500 \mathrm{~m}$ isobaths. Another area located west of the Strait, to the south of the ports of Barbate and Conil, was identified as a fishing area for the silver scabbardfish (Fig. 3).

Blackspot seabream fishing grounds during the studied years 2000-2011, as derived from the filtering on the total voracera fleet data, were quite contiguous and characterized by small patches. These positions coincide with traditional $P$. bogaraveo fishing zones previously described by Gil and Sobrino (2006). However, in 2011, some boats moved to a distant fishing area on the Atlantic side of the area (green circle on Fig. 3). This western area is also fished by other fleets from Conil with a different type of longline gear.

CPUE1 estimated from total landings and number of sales decreased from 67 to $42 \mathrm{~kg} \mathrm{day}^{-1}$ from 2009 to 2011 for the total voracera fleet (Table 1). The values and decline of CPUE1 for the fleet equipped with the SLSEPA device is similar (64 to $40 \mathrm{~kg} \mathrm{day}^{-1}$ ). As expected, CPUE2, where the effort is estimated from the SLSEPA device, was smaller than CPUE1 due to missing effort; it also declined slightly more, by $44 \%$ compared to $38 \%$, for $C P U E 1$. In addition to declining $C P U E$, these results show a decline in fishing effort from 98 days per vessel equipped with the SLSEPA device in 2009 to 75 days per vessel in 2011. Lastly, the proportion of missing effort (how much effort is not accounted for when
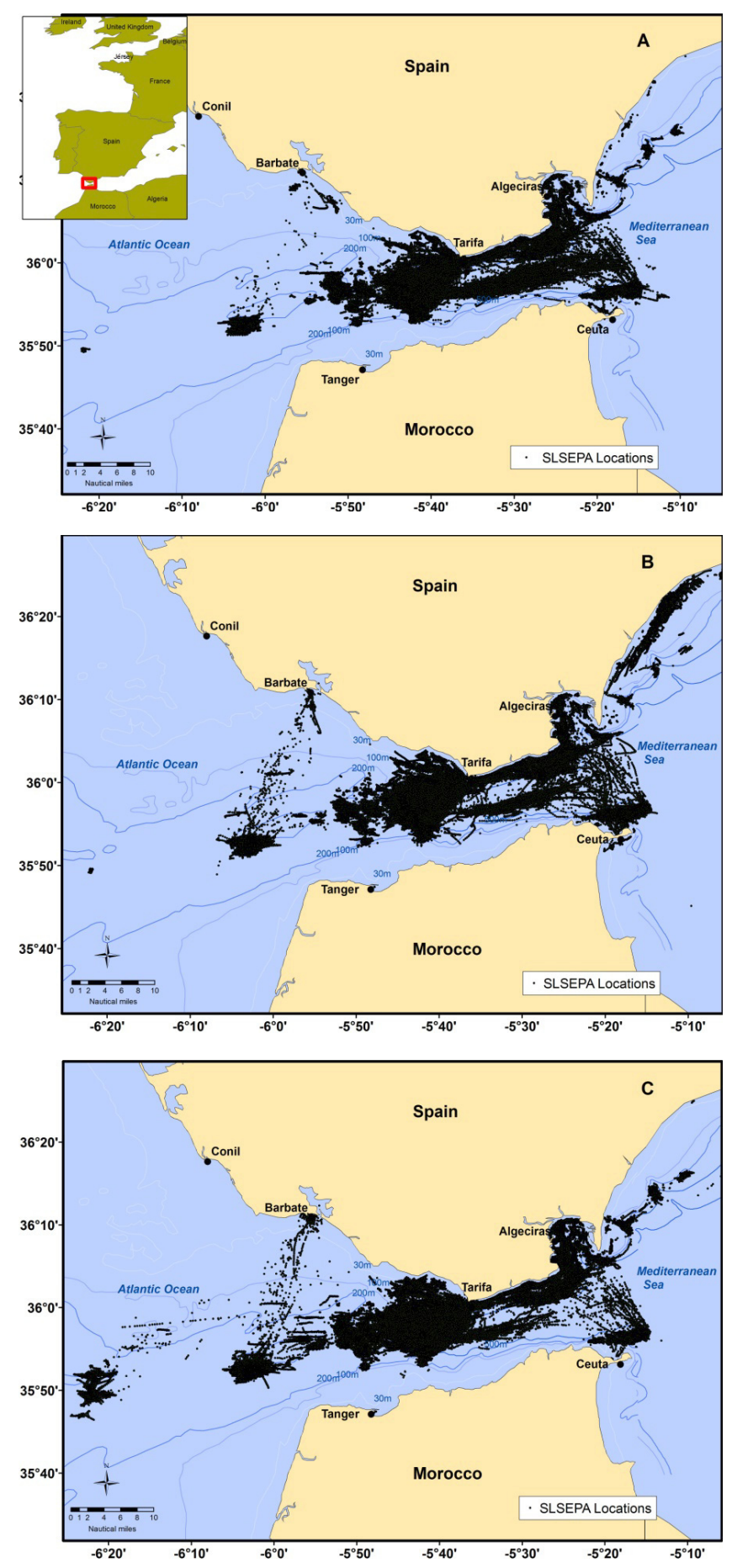

Fig. 1. Total (unfiltered) points distribution from SLSEPA records of the voracera fleet in the Strait of Gibraltar, (A) 2009; (B) 2010; (C) 2011 .

CPUE1 is used) almost doubled from 2009 to 2011, increasing from $14 \%$ to $24 \%$, coinciding with the decrease in stock abundance after 2009, the last peak in landings.

The cross validation with the information from the 2009 on-board observers program (Table 2) showed that, in around $25 \%$ of cases, the number of hauls estimated was equal to the observed number of hauls. However, in $85 \%$ of cases, 
Table 1. Estimates of fishing effort and CPUEs targeting blackspot seabream of the voracera fleet: estimations based on regional VMS (SLSEPA) and fishery statistics (sales sheets).

\begin{tabular}{llccc}
\hline Data source & & 2009 & 2010 & 2011 \\
\hline & No. Boats & 85 & 82 & 82 \\
Fleet & No. Sales & 7200 & 5863 & 4711 \\
equipped & Fishing days (trips) & 8373 & 7238 & 6160 \\
with & Fishing operations (hauls) & 60593 & 46579 & 38345 \\
SLSEPA & Blackspot seabream landings (kg) & 459010 & 274882 & 190786 \\
devices & CPUE 1 (Landings/Sales) & 64 & 47 & 40 \\
(green boxes) & CPUE 2 (Landings/Fishing days) & 55 & 38 & 31 \\
& CPUE 3 (Landings/Hauls) & 8 & 6 & 5 \\
& Proportion (\%) of missing effort ([Fishing & 14 & 19 & 24 \\
& days-No. Sales]/Fishing days) & & & \\
\hline \multirow{5}{*}{$\begin{array}{l}\text { Total } \\
\text { voracera }\end{array}$} & No. Boats & 87 & 92 & 86 \\
fleet & No. Sales & 8677 & 7029 & 5725 \\
& Estimated fishing days (trips) & 10564 & 9627 & 7741 \\
& (Landings/VMS CPUE2) & N/A & N/A & N/A \\
& Fishing operations (hauls) & 579140 & 365603 & 239751 \\
& Blackspot seabream landings (kg) & 67 & 52 & 42 \\
\hline
\end{tabular}

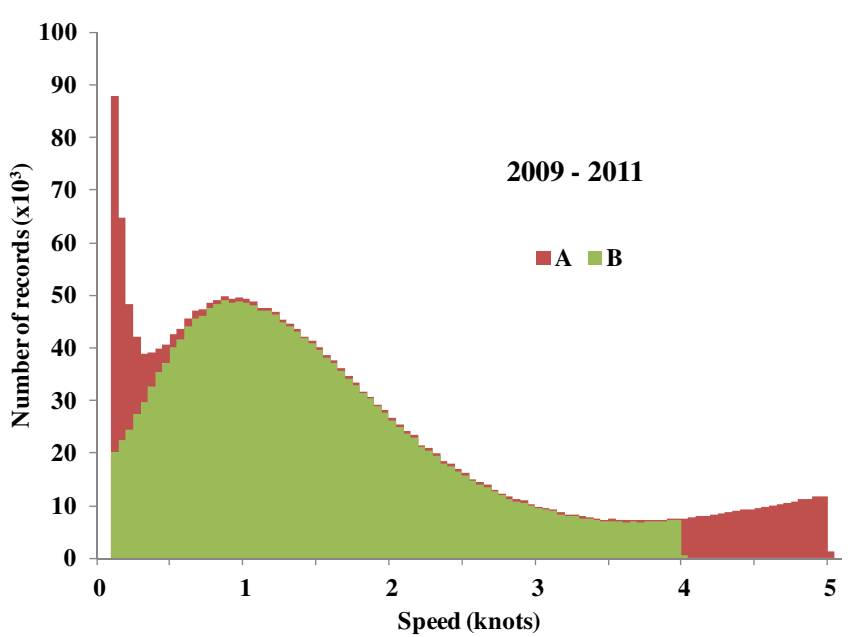

Fig. 2. Observed speed (knots) in SLSEPA records 2009-2011; (A) raw data provided by the Andalucía Regional Government; (B) filtered data removing records close to harbour, and at speed $>4$ knots.

differences between estimated hauls and observer data was $\leqslant 2$ hauls. Moreover, differences in the total number of hauls (479 estimated-498 observed) were only $4 \%$ and the average number of hauls per day estimated from the SLSEPA data and observed was similar for the three compared vessels.

For each year, maps of the estimated number of hauls targeting blackspot seabream per $1 \mathrm{nmi}^{2}$ cells show that most fishing is concentrated in a few specific areas, although some fishing occurs throughout the Strait of Gibraltar (Fig. 4). The corresponding spatial distribution of CPUE3 (Landings per haul) was less aggregated (Fig. 5) and the highest values of the $C P U E$ were obtained in more distant fishing grounds each

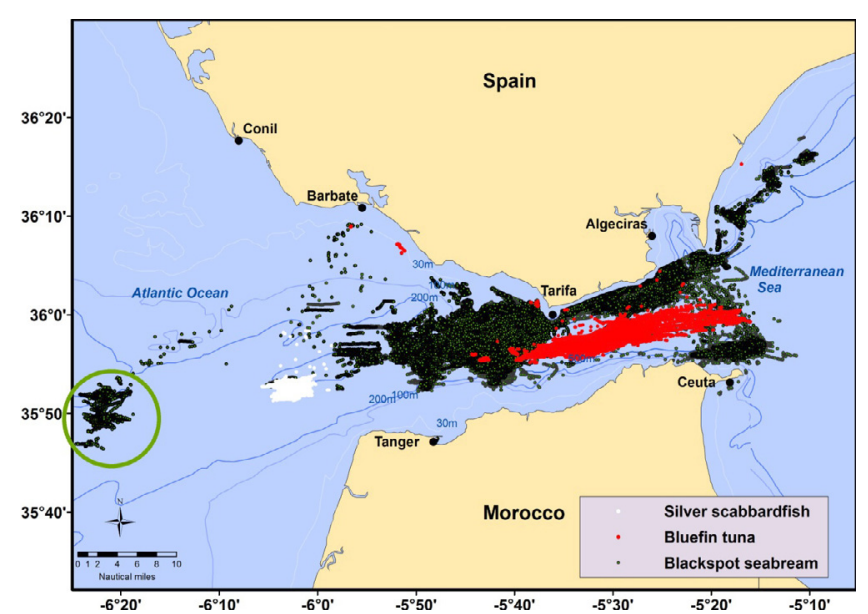

Fig. 3. Location of the fishing areas identified from SLSEPA and landings data during the study period (2009-2011) for blackspot seabream (black dots), Atlantic bluefin tuna (red dots) and silver scabbardfish (white dots). The green circle delineates fishing grounds not exploited by the voracera fleet before 2011 .

year (close to Ceuta in 2010 and on the new westernmost fishing ground in 2011). The spatial distribution of the quarterly $C P U E$ only suggests minor variations in the overall spatial distribution (not shown). However, higher $C P U E$ s were observed during the first quarter, which includes the fishery closure season (two months).

\section{Discussion}

Vessel Monitoring Systems (VMS) are increasingly used for quantifying fishing activities and the impact of fishing on 
Table 2. Cross validation of the estimated number of hauls per vessel from SLSEPA data analysis with the on-board observations in 2009.

\begin{tabular}{|c|c|c|c|c|c|c|c|c|c|c|c|c|c|c|c|c|c|}
\hline \multirow[t]{2}{*}{ Vessel } & \multirow{2}{*}{$\begin{array}{l}\text { No. } \\
\text { Trips }\end{array}$} & \multicolumn{9}{|c|}{$\begin{array}{c}\text { Differences (Estimated - Observed) } \\
\text { No. Hauls }\end{array}$} & \multicolumn{3}{|c|}{$\begin{array}{c}\text { Agreement } \\
(\%)\end{array}$} & \multicolumn{2}{|c|}{$\begin{array}{c}\text { Total } \\
\text { No. Hauls }\end{array}$} & \multicolumn{2}{|c|}{$\begin{array}{c}\text { Average } \\
\text { (Hauls/Trip) }\end{array}$} \\
\hline & & -5 & -4 & -3 & -2 & -1 & 0 & 1 & 2 & 3 & 4 & Equal & $\leqslant 2$ & Estim. & Obs. & Estim. & Obs. \\
\hline $\bar{A}$ & 21 & & & 2 & 2 & 3 & 5 & 3 & 5 & 1 & & 24 & 86 & 167 & 164 & 8 & 8 \\
\hline B & 24 & 1 & 1 & 1 & 6 & 8 & 6 & 1 & & & & 25 & 88 & 140 & 171 & 6 & 7 \\
\hline $\mathrm{C}$ & 23 & & & & 2 & 5 & 6 & 7 & & 1 & 2 & 26 & 87 & 172 & 163 & 7 & 7 \\
\hline Total & 68 & 1 & 1 & 3 & 10 & 16 & 17 & 11 & 5 & 2 & 2 & 25 & 87 & 479 & 498 & 7 & 7 \\
\hline
\end{tabular}
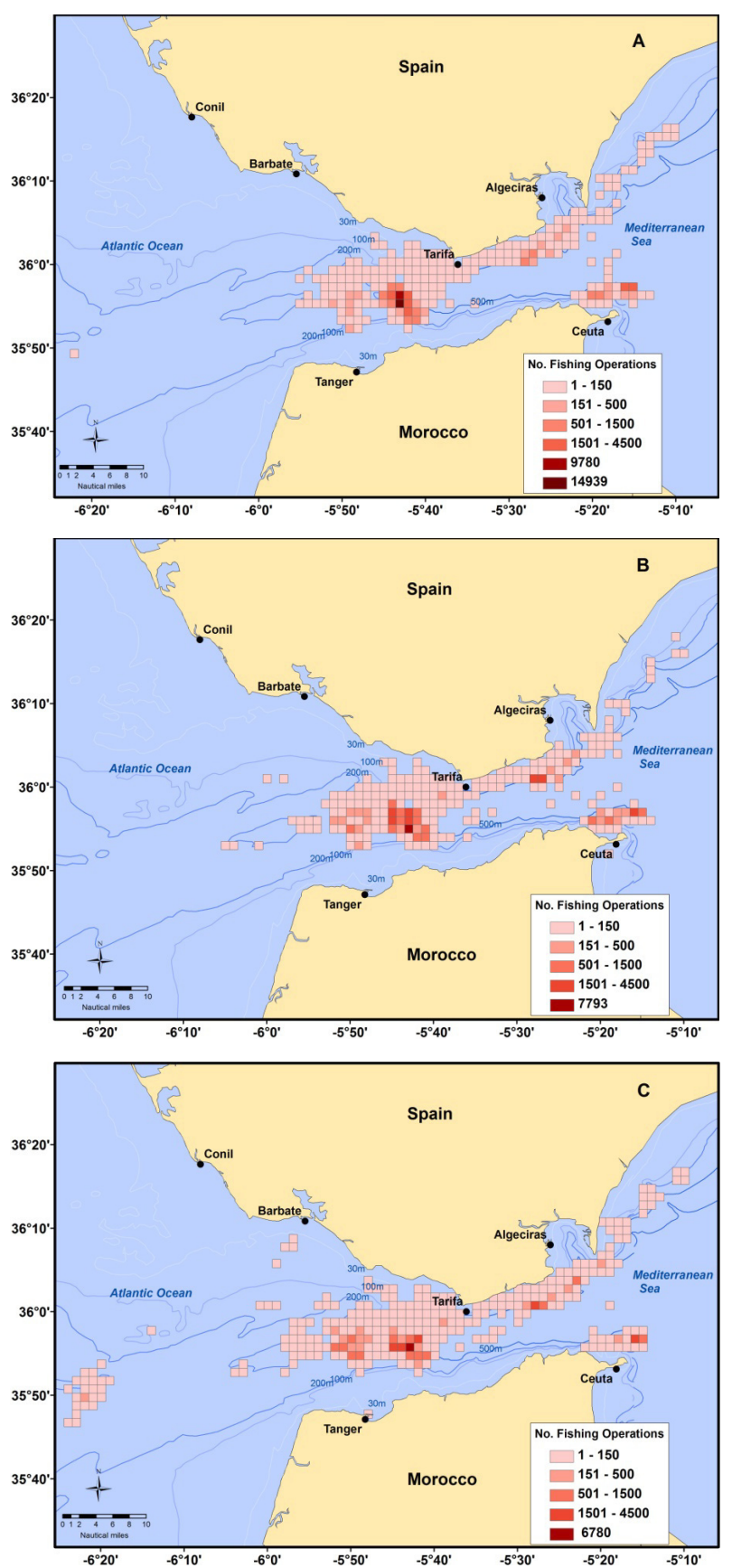

Fig. 4. Estimated number of fishing operations (hauls) for blackspot seabream by $1 \mathrm{nmi}^{2}$ cells from SLSEPA data: (A) 2009; (B) 2010; (C) 2011 .
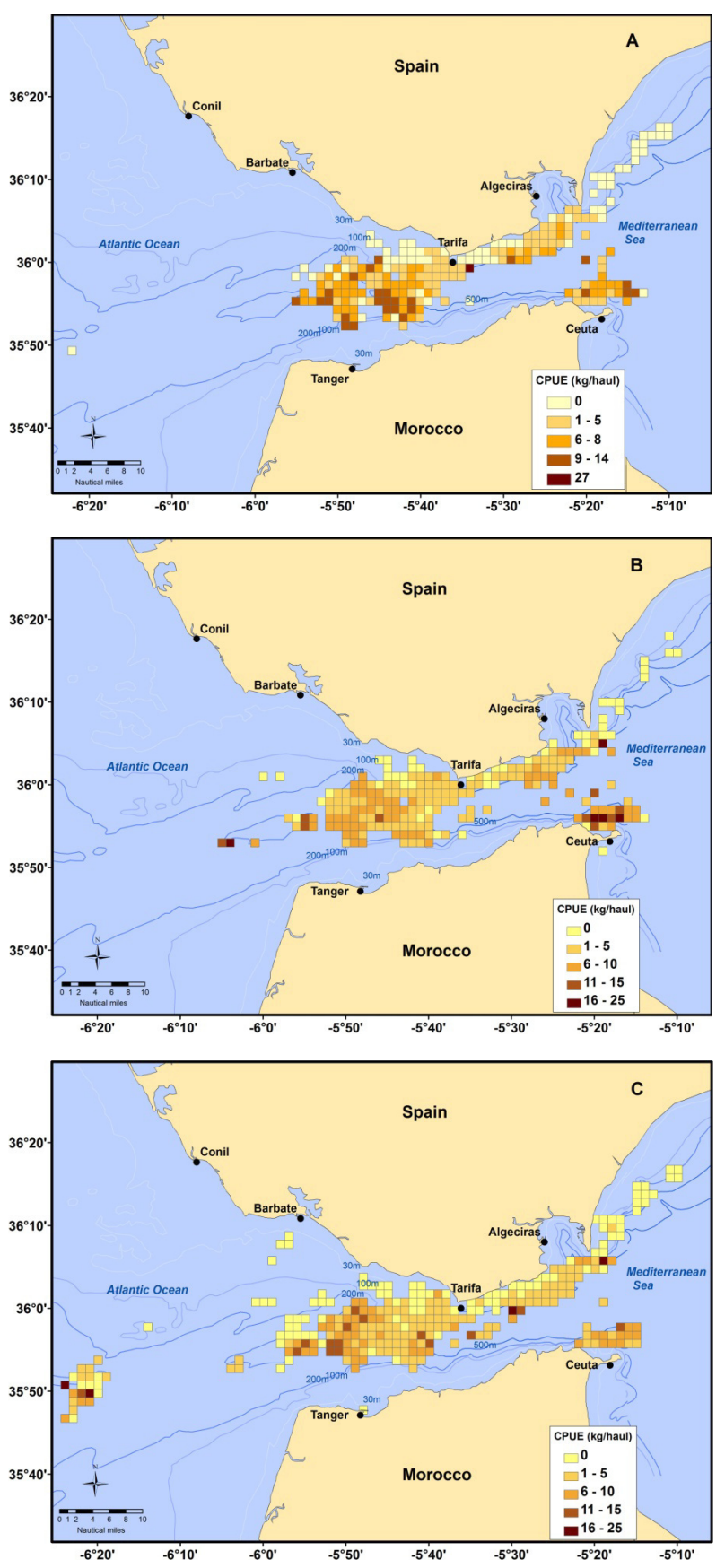

Fig. 5. Spatial distribution of the blackspot seabream CPUE3 (kg/haul) by year derived from SLSEPA data: (A) 2009; (B) 2010; (C) 2011 . 
ecosystems (e.g., Rice et al. 2012; Jennings and Lee 2012; Piet and Hintzen 2012). These systems provide valuable information that can be used for monitoring and management of marine resources in terms of spatial planning and monitoring the pressure and impact of fishing activity on the seafloor (CEC 2007). Several papers about its application to different topics are available for fishing activity mapping (Witt and Godley 2007), analysis and visualization of VMS data and fisheries logbooks (Hintzen et al. 2010) or development performance indices of commercial fisheries (Mullowney and Dawe 2009). Working with this kind of data can introduce biases and errors that need to be considered when interpreting the analyses. Most analyses are based on satellite-based VMS where records are transmitted on long time intervals, with the risk that records classified as fishing would be incorrectly classified. Moreover, Deng et al. (2005) assessed that, in bottom trawl fisheries, the biases increases with time interval and the loss of precision is quite marked with polling interval longer than $30 \mathrm{~min}$. Transmission data from the vessel to the land station via satellite is quite expensive, consequently data are generally transmitted much less frequently, often every 1-2 h.

GPRS/GSM technology allows higher frequency transmission at lower cost, although it is limited by the distance to the coast (about $16 \mathrm{nmi}$ ). Therefore, this system is suitable for artisanal fisheries. In our case, data are transmitted every three minutes maximum, which is a very high frequency compared with usual VMS frequencies. Interpolation or misunderstandings bias might be avoided to obtain accurate and reliable point density estimates of the fishing activity distribution (Lambert et al. 2012).

To the best of our knowledge, GPRS/GSM technology is rarely used for fisheries monitoring, but similar systems are being installed in fishing fleets, e.g., the Inshore VMS (I-VMS) in some protected areas of UK, the Croatia VMS, or the new system developed by the Centro de Investigación y Estudios Avanzados del Instituto Politécnico Nacional (Cinvestav-IPN) in Yucatán (Mexico).

SLSEPA data provides high spatio-temporal resolution data of the voracera fleet targeting blackspot seabream and allowed accurate and unbiased estimates of fishing effort and CPUEs to be calculated for this small-scale artisanal fishery.

The filtering process used was simple and excluded only port entries and exits, high speed records corresponding to steaming, and records located in shallow waters where the blackspot seabream is not targeted. The upper (4.0 knots) speed limits used to determine fishing activity were supported by the post-filtering frequency distribution of boat speeds, with a clear mode close to 1 knot. The distribution of speeds around this mode could be due to the environmental variability in the Strait of Gibraltar region (e.g., winds, tides and current strengths) or to different fisher's behaviours.

The association of fishing trips resulting in fish sales made it possible to identify fishing grounds for the three species targeted by the fleet and to allocate fishing trips that did not result in sales to a target species.

Estimating the number of fishing days by this procedure overcomes the problem of fishing trips resulting in zero or very small catches being ignored, as they can be with previous effort estimates based upon the number of sales. The differences between estimated fishing days and sales numbers provide a missing effort estimate. The increase in missing effort from 14 to $24 \%$ observed over the 3 studied years strongly suggests that realistic stock trends cannot be derived from landings and sales data and that the accurate fishery monitoring provided by the SLSEPA is necessary.

Daily trips could be reliably split into several fishing hauls, as shown by the good agreement between the number of hauls estimated from SLSEPA data and those recorded by on-board observers. The objective was to allocate the voracera fishing effort in greater geographical detail so that these fishing haul estimates could be used as another metric of fishing effort and allow a higher spatial resolution.

Associating VMS effort data with logbook or sales landings data has been reported to be challenging because the datasets can have different temporal scales, and several potential types of relationship between daily records could be found (Lee et al. 2010). In the present study, SLSEPA data could be reliably linked to sales information, because trips never last for more than one day (although sometimes the sale may occur the next day). Apportioning landings data to fishing hauls allowed the spatial distribution of the catch to be mapped. However, allocating boat daily catches equally to fishing hauls makes the assumption that the catch rate is the same in all hauls for a given boat and day (Gerritsen and Lordan 2011).

Hence, especially when dealing with spatial management, the information obtained from linked VMS and logbook (or landings) data plays an important role (Dinmore, 2003; Murawski et al. 2005; Pedersen et al. 2009), where spatial activity information is used to facilitate the process in designing marine protected areas or inform stakeholders on fishing impact. The voracera fleet activity targeting the blackspot seabream appeared quite similar through the years, and even quarterly. Nevertheless, some boats fished in quite distant fishing grounds in the last year, probably because of the decreasing catch rates. Further fishery monitoring might allow assessment of whether this trend will continue.

The estimated trend in $C P U E$ suggests that the blackspot seabream abundance in the Strait of Gibraltar decreased in recent years. Whether the change in CPUEs is proportional to that of the stock abundance is not known for that particular fishery; both processes of hyperstability, i.e., catch rates declining slower than abundance, and hyperdepletion, i.e., catch rates declining faster than abundance, have been shown to happen even for a single stock at different abundance levels (Roa-Ureta 2012) and may even affect survey data (Davies and Jonsen 2011). As a consequence, although CPUEs estimated here might be considered as a useful stock indicator that can be used for assessment and management, further work is needed to evaluate the properties of this indicator and longer time series analyses would be required to confirm such a trend.

The observed CPUE trend is expected to trigger management action in the near future. As for stocks assessed from trends with no biomass reference point, such as in the present case, ICES advises catches to be decreased proportionally and then further decreased by $20 \%$. Unfortunately, this only applies to Spanish catches and other catches (mostly Portuguese) of blackspot seabream in ICES Division IXa (west Iberia) but not to catches in the Mediterranean Sea that are not managed 
using Total Allowable Catch (TAC). In the Mediterranean Sea, the stock is also exploited by Morocco, whose fishery is poorly known, although the fishing grounds overlap which those of the voracera fleet (Castilla Espino et al. 2006).

Finally, the fine scale description of the fishing activity provided by the SLSEPA monitoring may allow for the implementation of spatial management measures in addition to the TAC. Clearly, if the stock appeared to continue declining in the future, it could be easier to set closed areas applicable to all fleets than to implement a TAC for fleet fishing in the Mediterranean Sea, where this management tool is not used.

\section{Conclusion}

This paper introduces a method to estimate fishery indicators of a small-scale artisanal fishery, based on a vessel monitoring system using GPRS/GSM technology for transmissions, which allows a higher data frequency.

Overall, this study developed fishing effort and CPUE estimates based upon regional monitoring of the fishing activity of the voracera fleet targeting the blackspot seabream. These indicators are highly relevant to fishery assessment and management. The method used could be useful for other small-scale fisheries in Europe and elsewhere. The high frequency data allow spatial analysis of the fishing activity, which is rarely available for small-scale fleets, even though their management can be critical at the regional level.

In addition to the estimation of fishing effort, maps of spatial distribution are relevant in the case of linking georeferenced fishing boat activities with landings. SLSEPA send data every three minutes, allowing for an accurate estimate of the actual fishing activity using a quite simple method not relying on strong assumptions. Fishery indicators or effort, catch rate (CPUE) and their spatial distribution are reliable. As expected, the "missing effort" increased with decreasing catch rates, i.e., with likely decreasing resource level. The spatial distribution of the effort seems to be spreading with decreasing catch rates, suggesting that fishers explored fishing grounds further when catches declined. In this study, integrated analysis of VMS and sales information allowed working at a considerably finer spatial scale than in the past. The next challenge could be to combine these data with climatic and oceanographic conditions to interpret the fishing strategy, i.e., the choice of target species and fishing grounds at a fine spatio-temporal scale.

Acknowledgements. This study was carried out with the data and financial support from the Junta de Andalucía Government (Agriculture and Fisheries Department) and with financial support of the FP7 DEEPFISHMAN project (Grants agreement No. 227390). All Regional VMS and logbook data were aggregated at such a level that the confidentiality of individual vessels was not compromised. Finally we would thank Pascal Lorance and two anonymous referees for their encouragement and valued comments on previous versions of this paper. DEEPFISHMAN A FP7 Project (2010): Management and Monitoring of Deep-Sea Fisheries and Stocks. Case Study 3a Report. Red Seabream in the Strait of Gibraltar.

\section{References}

Anonymous, 2010, DEEPFISHMAN A FP7 Project.

Castilla Espino D., García del Hoyo J.J., 2006, Medición de la capacidad de pesca de la flota de voraz del Estrecho de Gibraltar: enfoques paramétricos y no paramétricos. Estud. Agrosoc. Pesq. 210, 115-154.

CEC, 2007, European Parliament legislative resolution of 11 December 2007 on the Council common position for adopting a directive of the European Parliament and of the Council establishing a Framework for Community Action in the field of Marine Environmental Policy.

Davies T.D., Jonsen I.D., 2011, Identifying non proportionality of fishery-independent survey data to estimate population trends and assess recovery potential for cusk (Brosme brosme). Can. J. Fish. Aquat. Sci. 68, 413-425.

Del Olmo L.A., 2006, Localización y seguimiento de Embarcaciones pesqueras andaluzas. Agromar Andalucía - Revista de Información de la Consejería de Agricultura y Pesca de Andalucía 37, 30-37

Deng R., Dichmont C., Milton D., Haywood M., Vance D., Hall N., Die D., 2005, Can vessel monitoring system data also be used to study trawling intensity and population depletion? The example of Australia's northern prawn fishery. Can. J. Fish. Aquat. Sci. 62, 611-622.

Die D., Ellis N., 1999, Aggregation dynamics in penaeid fisheries: banana prawns (Penaeus merguiensis) in the Australian Northern Prawn Fishery. Mar. Freshw. Res. 50, 667-675.

Dinmore T.A., Duplisea D.E., Rackham B.D., Maxwell D.L., Jennings S., 2003, Impact of a large-scale area closure on patterns of fishing disturbance and the consequences for benthic production. ICES J. Mar. Sci. 60, 371-380.

Diputación Provincial de Cádiz, 1991, El Sector Pesquero en la Provincia de Cádiz. Excma. Diputación de Cádiz.

Espino D.C., del Hoyo J.J.G., Sharp B.M.H., 2005, Capacity and capacity utilization of the "voracera" fleet in the Strait of Gibraltar. Mar. Resour. Econ. 20, 367-384.

Fock H., 2008, Fisheries in the context of marine spatial planning: defining principal areas for fisheries in the German EEZ. Mar. Policy 32, 728-739.

Gerritsen H., Lordan C., 2011, Integrating vessel monitoring systems (VMS) data with daily catch data from logbooks to explore the spatial distribution of catch and effort at high resolution. ICES J. Mar. Sci. 68, 245-252.

Gil J., 2006, Biología y pesca del voraz [Pagellus bogaraveo (Brünnich, 1768)] en el Estrecho de Gibraltar. Tesis doctoral. Facultad de Ciencias del Mar Y Ambientales. Universidad de Cádiz.

Gil J., Sobrino I., 2006, La pesquería del voraz en el estrecho de Gibraltar. In: Acuicultura, pesca y marisqueo en el Golfo de Cádiz. Consejería de Agricultura y Pesca. Junta de Andalucía. CD ROM.

Hilborn R., Walters C.J. (Eds.), 1992, Quantitative fisheries stock assessment: choice, dynamics and uncertainty. Chapman and Hall, London.

Hintzen N.T., Piet G.J., Brunel T., 2010, Improved estimation of trawling tracks using cubic Hermite spline interpolation of position registration data. Fish. Res. 101, 108-115.

ICES, 2012a, Report of the Working Group on the Biology and Assessment of Deep-sea Fisheries Resources (WGDEEP), Copenhagen, 28 March-5 April, Denmark. ICES CM 2012/ACOM: 17, 929 pp.

ICES, 2012b, ICES implementation of Advice for Data-limited stocks in 2012 in its 2012 advice. ICES CM 2012/ACOM: 68, 28 pp. 
Jennings S., Lee J., 2012, Defining fishing grounds with vessel monitoring system data. ICES J. Mar. Sci. 69, 51-63.

Lambert G.I., Jennings S., Hiddink J.G., Hintzen N.T., Hinz H., Kaiser M.J., Murray L.G., 2012, Implications of using alternative methods of vessel monitoring system (VMS) data analysis to describe fishing activities and impacts. ICES J. Mar. Sci. 69, 682-693.

Lee J., South A.B., Jennings S., 2010, Developing reliable, repeatable, and accessible methods to provide high-resolution estimates of fishing-effort distributions from vessel monitoring system (VMS) data. ICES J. Mar. Sci. 67, 1260-1271.

Lorance P., 2011, History and dynamics of the overexploitation of the blackspot seabream (Pagellus bogaraveo) in the Bay of Biscay. ICES J. Mar. Sci. 68, 290-301.

Lorance P., Pawlowski L., Trenkel V.M., 2010, Standardizing blue ling landings per unit effort from industry haul-by-haul data using generalized additive models. ICES J. Mar. Sci. 67, 1650-1658.

Matthews K.B., Rivington M., Blackstock K., McCrum G., Buchan K., Miller D.G., 2011, Raising the bar? - the challenges of evaluating the outcomes of environmental modelling and software. Environ. Model. Software 26, 247-257.

Mullowney D.R., Dawe E.G., 2009, Development of performance indices for the Newfoundland and Labrador snow crab (Chionoecetes opilio) fishery using data from a vessel monitoring system. Fish. Res. 100, 248-254.

Murawski S.A., Wigley S.E., Fogarty M.J., Rago P.J., Mountain D.G., 2005, Effort distribution and catch patterns adjacent to temperate MPAs. ICES J. Mar. Sci. 62, 1150-1167.
Padillo J., Carrera J.J., Diputación Provincial de Cádiz, 2001, Las artes de pesca en el Litoral gaditano. Diputación Provincial de Cádiz.

Pedersen S.A., Fock H., Krause J., Pusch C., Sell A.L., Böttcher U., Rogers S.I., 2009, Natura 2000 sites and fisheries in German offshore waters. ICES J. Mar. Sci. 66, 155-169.

Piet G.J., Hintzen N.T., 2012, Indicators of fishing pressure and seafloor integrity. ICES J. Mar. Sci. 69, 1850-1858.

Roa-Ureta R.H., 2012, Modelling in-season pulses of recruitment and hyperstability-hyperdepletion in the Loligo gahi fishery around the Falkland Islands with generalized depletion models. ICES J. Mar. Sci. 69, 1403-1415.

Rice J., Arvanitidis C., Borja A., Frid C., Hiddink J.G., Krause J., Lorance P., Ragnarsson S.A., Skold M., Trabucco B., Enserink L., Norkko A., 2012, Indicators for Sea-floor Integrity under the European Marine Strategy Framework Directive. Ecol. Ind. 12, 174-184.

Silva L., Gil J., Sobrino I., 2002, Definition of fleet components in the Spanish artisanal fisheries of the Gulf of Cádiz (SW Spain, ICES Division IXa). Fish. Res. 59, 117-128.

Stelzenmüller V., Rogers S.I., Mills C.M., 2008, Spatio-temporal patterns of fishing pressure on UK marine landscapes, and their implications for spatial planning and management. ICES J. Mar. Sci. 65, 1081-1091.

Witt M.J., Godley B.J., 2007, A step towards seascape conservation: using vessel monitoring systems (VMS) to map fishing activity. PLoS One 2: e1111. DOI: 10.1371/journal pone.0001111. 